Slavomir Miletić, $\mathrm{PhD}$

University of Priština, Faculty of Economics

Kosovska Mitrovica

Đuro Đurović, PhD

Belgrade business school - Higher education institution for applied studies
SCIENTIFIC REVIEW ARTICLE

Received: February 05, 2015

Accepted: March 11, 2015

\title{
IMPROVING ENTERPRISE INTERESTS THROUGH THE PROCESS OF BUSINESS COMMUNICATION
}

\begin{abstract}
This paper is treating the problematics of communication as a vital part of business, organisation and management. Communication is an important company factor that can represent the border between its success and failure. Business communication is like an enterprise bloodstream that reflects healthy balance in its work. It is that communication that is used in different purposes, often product promotion, services or companies. Affability, accuracy, influence, consistency and tidiness of communication are qualities that are supposed to contribute to enterprise positive experience expression.

Every enterprise is trying to create a communication style of their own that is structured by the surroundings that it operates in. Enterprises can use different options of promotion to achieve inside out and inside in goals, in different situations. Providing modern equipment or technologies isn't enough. It is more important to master the market and its laws, create good relationships with clients and government institutions, and continuously improve knowledge. There are more and more lobbyists recently that use their abilities with public relations techniques in times of great value for lobbying or changing the attitude of the public or those that make decisions.
\end{abstract}

Keywords: enterprise, business communication, promotion, lobbying, information.

JEL classification: M21, M37, M48

\section{УНАПРЕЪЕЊЕ ИНТЕРЕСА ПРЕДУЗЕЪА КРОЗ ПРОЦЕС ПОСЛОВНОГ КОМУНИЦИРАҢА}

\begin{abstract}
Апстракт
Рад третира проблематику комуникачије као виталаног дела пословања, организачије и менацмената, полазећи од премисе да је она значајан фактор утиска о предузећу који може представљати гранииу између његовог успеха и неуспеха. Пословна комуникација делује као крвоток у предузећу и одражава здраву равнотежу у његовом деловању. То је комуникащија која се користи у различите сврхе, а најчешће за промочију производа, услуга или предузећа. Сусретьивост, тачност, утицај, доследност и уредност комуницирања су квалитети који треба да доприносу унапредјењу позитивног искуства о предузећу.

Свако предузеће настоји да креира сопствени комуникацијски стил структуриран према окружењу у којем делује. У различитим ситуацијама
\end{abstract}


предузећа могу користити различите опщије промовисања инсиде оут и оутсиде ин ичивева у лобирању. Није довољно само обезбедити савремену опрему или технологију, много је важније овладати тржиштем и његовим законитостима, успоставити добре односе са клијентима и државним институцијама и континуирано усавршавати знање. У последње време све је више лобиста који своје способности користе заједно са публиц релатионс техникама у тренуцима од велике важности за лобирање или мењање става јавног мњења или оних који одлучују.

Кључне речи: предузеће, пословно комуницирање, промовисање, лобирање, информација.

\section{Introduction}

Globalisation and modern technologies are key forces that design a new level of connections in the world economy. Global market changes in the surroundings are bringing constant increase of the market competitors and they are strengthening competitiveness. In that conditions, only active competitors that have the ability to do business by new market rules and principles can count on adequate tretmans and affordable economic perspective if they know how to communicate. The business social sphere is related to social and economic norm integration. Science and technology are advancing fast. These trends of development in this areas have to be closely monitored and applied in business. Communication can set boundaries between successful and a failed enterprise and generally the idea of it.

Business communication is the one that is used to promote products, services or company interests. It is a transfer of information within the business world or to the appropriate official government institutions. The purpose of successful communication is lobbying, transfer of information, messages and experience. That includes creating new ideas by agreement, opinion harmonization, and arguments even by refutation. Communication works like a bloodstream in the enterprise and it keeps healthy balance in their functioning. Every enterprise needs to have their communication style that is structured within its context.

Improving enterprise interests by adequate communication is in the foreground. Besides promotion of defined enterprise interests, consultant tasks are diversified in that sense that they work on bringing investments to Serbia and to acquire contacts with different companies that are interested to invest in our small country. One of the key activities of national lobbies association is helping local enterprises at opening to other markets and to strengthen relationships with multinational companies.

Variable surroundings is forcing enterprises to change for survival. That way of adjustment has to be partnered with the state. The state needs to give appropriate help to achieve successful market competition.

\section{Modern enterprise and instructional surroundings}

Difficulties that modern enterprises are faced, as well as world trends on the area of market globalisation, impose many urgent challenges that are necessary to answer. It is about confrontation with different shapes of integrative processes and accelerated 
globalisation. Modern enterprise is forced to find an option so it could oppose to negative influence of market movement, and adjust to new business ways. That efforts need to be monitored by successful business communication and functioning in the newly created economic, social and informational environment.

Knowing state political chances in the business conditions in which the economic crisis end is seen is very important. State regulative and political environment are acting as the power to develop business, economy functioning, enterprise survival and at the end. For an enterprise to function successfully in the current business criteria, it is necessary to bring strategically important decisions using the right way. Guided by innovation and technology achievements, only those enterprises that are capable of effective adjusting to the rules of the game that is imposed to new business trends (Djordjević, 2012, p. 17-18) can survive on the world market.

Those business trends are:

- $\quad$ economic sustainability, building fundamental strategies to generate growth;

- building company compromises between employees and employers in sense of improving quality of their business;

- introducing world achievements in areas of organisation, management techniques and methods, implementing modern information technology;

- $\quad$ stable state regulatives and understanding the political context.

Economy depression is steering the world functioning. The only defence of economic enterprise collapse is understanding its logics. Globalised world is faced by visible discrepancy. Global market is opening perspective to unimaginable wealth, and at the same time is increasing its vulnerability and the hazard of rift between those that are a part of the globalised world and those who aren't, to political disputes and more certain war confrontation. Faced with unpredicted environmental changes and the fast world economy tempo, modern enterprises are found on a seesaw. They have to decide between big business risks and great opportunities that are offered on the market. The problem is creating a quality choice and to let go to new tendencies. If enteprise management is following technological trends and requirements of global economy, then the selection will be easier.

The consequence of this market situation is the fact that a great number of enterprises are excluded from business. Enterprises like that couldn't balance in the environment that is liable to constant change. The number of enterprises is increasing on the wrong side of the change chart. There is also an increase of the number of enterprises that are tangled in the nets of value and economic systems that they have little control of. Enterprise survival is conditioned by changes of the model of business (www.gendar. rs/Poslovno-komuniciranje.aspx) communication. Providing modern equipment or technologies isn't enough. It is more important to master the market and its laws and to create good relationships with institutions. To achieve that they need to monitor market indicators and information related to user requests and the level of their satisfaction. Special attention needs to be given to the analysis of competitors. It is hard to get successful fundamental business premise today, because the competition is countless, and consumer requests are getting harder to meet. Enterprise business prosperity depends of their ability to modify their products to customer requests and needs, and to meet world standards for the technology and quality of products.

Changed economic conditions are requiring new approaches in business practise. The enterprise has to behave in that way that it becomes a leader in its functioning, to offer the market what the competition isn't, by satisfactioning consumer needs the right 
way. Initial step is the right management informativeness on market changes needs. To provide information that are related to user requests and the level of their satisfaction, as well as information on competitors (Hamel \& Breen, 2007, p.21) is the key challenge that stands before every enterprise. In that sense, it is necessary for a company to have information processing systems on high business performance. Those systems contain market data, consumers, suppliers, competition, employees, auctioneers, financial results etc. These systems provide adjustment to their business to recent trends, making business communication easy and fast transformation to enterprise leadership on the global market. Technology is providing fast, reliable and cheap information transfer through the world. It is providing relevant information to the management about environmental changes.

Of course, technology isn't the only precondition to enterprise business success. Human resources are key factors. Parallel to technology improvement, professional staff needs to be trained additionally. Without them, their commitment to continuously learn, the company can't keep up with the world. Every enterprise needs people that have leadership skills that can see the changes of environment and market as well as picking the optimal strategy and force their vision and transfer it to others.

Expected results of improving enterprise interests by adequate business communication (www.poslovnaznanja.com/objavljeni-autorski-tekstovi/e-magazin/) and promotion, can be assorted to a few base categories:

- goals that the enterprise is trying to put to reality by disabling wrong decisions

- $\quad$ goals that will insure the enterprise if the decision execution is postponed to uncertain time

- $\quad$ goals that the enterprise will realise if the change of key decisions

- goals that the enterprise will make by creating a political background of the problem, influencing on debates of the problem that is important to the enterprise.

Harmony and dynamics of economic changes require that the enterprise develops and builds competitive leadership and capabilities. Competitively oriented enterprise can offer products of higher quality and by more affordable conditions than the rivals. As the strategy lifetime decreases, every strategy that enterprise managers choose has to be clearly adjusted to environmental conditions. By choosing strategies it is defining not only focus and growth options of the enterprises, but at the same time it should be leading to competitive leadership form creation. It is urgent, because strategies connect modern information technology, reengineering and modern techniques and tools.

The orientation competitive concept of the enterprise is the mirror of its success. The enterprise can build their orientation in only one form of business improving, but can get to optimal results by combining different elements. That orientation means: (Miletić, 2010, p. 37)

- Fulfilling modern market requests with expected products and services according to previously researched needs

- $\quad$ Focusing on consumers and competition at the same time

- Improving and modifying quality of existing products

- Using most modern technological achievements and informational technology and systems

- Modernising the existing production process in new, advanced tools and equipment

Globalisation and the complex environment are forcing enterprises to change so they could survive on the market. Striving that goal, the enterprise will succeed in the market game 
by satisfactioning base economic principles. Help from the state can't be left behind on the way of adjustments and competition for the national economy to be more successful.

\section{Small, middle enterprises and business communication}

In developed countries, small and middle enterprises are the foundation of economic development and employment. They are the most vital and dynamic part of economy. The economic crisis has once again shown that small and middle enterprises are notably softening the fall of every national economy. They are the founders and movers of national economy as opposed to big enterprises, can have different rights and obligations. That's why they attach importance to development in every country. By strengthening their competitiveness, they are also strengthening the economy as a whole. There are special support programs in many states for small and middle enterprises that is conducted by the Government and the ministries in charge. The point of these programs (Ćirković, 2013, p. 71) is to facilitate access to credit funds, give start up information for starting and managing business, help by overcoming business problems, lowering the tax weight etc.

There is a number of criteria to be set to define micro, small and middle enterprise, as recommended by the European Commision. Most common criteria is the number of employees, total annual turnover or business property.

Table1. Defining small and middle enterprise in EU recommendation

\begin{tabular}{|l|c|l|l|}
\hline Category & No. of employees & Total annual turnover & Business property \\
\hline Micro enterprises & $0-9$ & Up to 2 milion $€$ & Up to 2 milion $€$ \\
\hline Small enterprises & $10-49$ & From 2 to 10 milion $€$ & From 2 to 10 milion $€$ \\
\hline Srednja preduzeća & $50-249$ & From 10 to 20 milion $€$ & From 10 to 43 milion $€$ \\
\hline
\end{tabular}

Source: Klepić, Z. i M. Buble, (2007), Small enterprise management basics of business, University, Mostar,

Significance an the role of small and middle enterprises in every developing economy and society is coming from the fact that they make the greatest number of enterprises in every market oriented economies. They face a great challenge in current conditions of economy to resist the premises of globalisation and the competitive market. For them to successfully develop, they need state support. In the sense of EU, the European commission is working on a wide spectre of political support functioning questions (Spahić, 2006) for small and middle enterprises of EU members. All support actions for small and middle enterprises are regulated through a unique and comprehensive law form. Small and middle enterprises are requesting support on a local level too, so the activities of the Commission imply helping member countries to build politics in function of improving entrepreneurship, improving the state of small and middle enterprises, securing access to new markets etc. Serbia, that is on the way of joining EU by creating favorable economy surroundings is supporting all recommended activities to small and middle enterprises.

Small and middle enterprise are a specific category for every national economy (Trbović, 2014) considering that they are the first to be hit with public decisions. That sensibility is seen in unsecure financial and commercial structure of small and middle enterprises, so the consequences of public decisions can be very serious for them. Their 
business activity is often limited to one product or service, so of the decisions are related to structure changes as an example, these enterprises can be seriously threatened.

Small and middle enterprise are facing a financial problem in the process of building effective communication with those that have formal and informal power of decisions. Decisions that affect the success of their business. These enterprises manipulate enough funds to secure the access to meetings and gatherings on which key decisions are made for their business. Business communication in a sense of lobbying is known to economies of developed countries in the West. For small and middle enterprises is almost unreachable to communication due to the fact that it has a high price, and it is not a priority of business. Insufficient lobbying is leading to that they don't have any influence in decisions and they leave an impression of complete disengagement

As a form of business communication, only lobbying is the strategic economic tool that is used to improve economic interests from some economic subject (one enterprise or a whole industry).

It is all likely that small and middle enterprises have to adjust to this form of business communication to successfully do business. To adjust they need to find ways of overcoming problems that follow this process. First recommendation is to stay away from acting on their own. Small and middle enterprises on a local, national, and maybe even regional level probably can withstand the cost of financing these communication activities. However, with every next instance, the cost of business communication (lobbying) can increase to that level that it would be hard to afford. Caution is advised because of that. Engaging lobbying consultants can be very expensive for them, but it is possible to make a monitoring business climate for a reasonable price.

Insufficient organisational structures matching in common associations that would lobby in their name are an another problem for small and middle enterprises. To overcome this business communication problem, small and middle enterprises are forced to use external results through intermediary structures. (Clamen, 2004, p.230) Different forms of association for small and middle enterprises carry certain challenges. It is important that the whole group interests overcome individual interests.

\section{Improving the interests of company with persuasion}

Persuasion is a complex activity of representatives with special interest, which is quite legitimate, because everyone has the right to protect and promote own interests no matter if they are economically or politically. The value that brings lobbying, conducted in a professional and ethical manner, depends on the concrete possibilities to find access to decision-makers in the institutional environment and the quality of the arguments and information offered in return, which are very often needed in management and positively affect on making their own decisions. Persuasion in Serbia in order to influence on business decisions of importance for the company is still an abstract concept. In our country, more than in other countries, prevailing opinion that lobbyists are people dealing with corruption, bribery and blackmail. For those reasons the main task of the official institutions and associations lobbyists is to break down prejudices about influencing as illegitimate procedure in business communication, as well as legally better regulate issues related to this topic.

Lobbying represents activities aimed to professional promotion, improvement or protection of special interest with the primary aim to influence on work of the legislature or the executive. Lobbying (www. rs.wikipedia.org/wiki/Lobiranje) make possible that interest find proper way to public officials in order to attract their attention and possibly 
obtain their support. That's why there are associations of employers, trade unions, union bakers and artists and other similar organizations.

From the economic point of view it is a defense and a commitment to the economic interests of certain companies or whole industries. For example, Lobbying for Serbian Government at the European Commission to achieve that higher export quotas for sugar beet in the EU. Corporate lobbying is kind of influence where it represents, promotes and defends certain narrow private interests of an industry or company. This is the most dominant example of persuasion and it is done either directly by industry, or through professional consultants. Institutional lobbying, however, is lobbying in the public sector, and is closely linked with economic lobbying, usually with some higher state or international institutions. Institutional lobbying implies that municipalities / regions lobbying at the federal level or with central authorities for obtaining development funds. The most commonly refers to the process of allocation of public funds to encourage economic activities, subsidies, etc, inside some political entity.

Potential lobbyists who may represent the interests of domestic companies and the entire economy in the institutions of the European Union and abroad in general, will have to obtain an appropriate license and be registered with the association. ( Kašćelan,\& Krsmanović, 2012, p. 157-158) The primary means by which lobbyists are trying to realize some influence in fact are the information, which has its stronghold in approach theory. (Bouwen, 2002) Influencing enables to emphasize the needs of the economy as a whole (branch / industry groups, companies) and civil society in process of political debate and making decisions. Center of the problem is not just simply collecting data, already the creation of original information through a multi-layered system of their collection, processing and adaptation. (Krsmanović, 2013, p.6)

In economic terms, the aim of these activities is, finally, to protect remaining Serbian brands in the country and the world and to build a better picture of our economy. In different situations, companies (including small and medium) will use a different options to promote the inside out and outside in goals in lobbying. For example, when a company seeks to promote new technological product on the market, it is necessary to influence the legislation. If the company wants to participate in a tender, it will strive to influence on change conditions of participation in the same. If company have aim to successfully implement a technological innovation, company will lobby to reduce political pressure. If it is necessary for the specific company to suspend the work, will influence for political agreement to reduce the negative consequences of that suspension. Also, the company will lobby against political support for the introducing a specific technological processes, introduction of technology or any other process that would work to the detriment of the product it produces. In a situation where interests of company are to expand its capacity, will lobby on their own behalf for changing the plan of spatial planning. Company will carefully and tactically through communication take a part in creating market policy as part of their economic activity. In order to help reach these funding companies will provide its business activities affect the conditions for obtaining investment or financial support, and so on. In order to easily reach these funds companies will through business activities make influence the requirements for obtaining investment or financial support, etc.

Therefore, successful lobbying imposes need to be well acquainted with the organizational structure of making decision, all the relevant levels of deciding, and even the names of decision makers. (Clamen, 2004, p. 65) 


\section{Promoting interests of enterprises through the activities of business communication}

Everything begins with the process of communication. Since communication is base in many areas of business, each company trying very seriously approach to the development of business communication skills. (Dobrijević, 2015, p. 7) In this regard, corporate communications (Cornelissen, 2004) are an important part of business strategy and policies of the organization. By applying appropriate methods of corporate communications companies can improve their market position and interests through the promotion of, and therefore the total business. Properly improved communication techniques can lead to a positive response of investors, and the overall competitiveness of the economy and transparency of public institutions. The degree of development in corporate communication (Djordjević, 2011, p. 196) is significant indicator of condition business awareness in company, and their relationship with the business environment in which they develop own market cycle.

In the existing environment, regardless whether it's a company, interest group or any other type of associations, lobbying as profession in function of good communication involves engaging the experts in that area. In any situations the lobbyists task is the same, using own skills of persuasion to create new relationships and improving existing ones between the business community and the public sector.

Lobbying can be treated as part of the process of public relations. Lately, there is more and more lobbyist who use their skills together with PR (Public Relations) techniques, in cases of great importance for influencing or changing attitudes of public opinion (www.co.rs/ODNOSI SA JAVNOSCU/OdnosiSaJavnoscu-.html) or attitudes of those who decide. Once, not without reason, Bill Gates said: "If I had one dollar left, I'd spend it on PR"! Connection between government and the mass media is one of the most important relations created during the process of lobbying. Mentioned relations helps to more precisely determine the areas in which lobbyists should operating.

Practically, lobbyists can represent both individual and general interests, which means that they can affect on decisions important for singularly enterprise, or for the benefit of the whole community. Since they have contact with representatives of the government and opportunity to acquainted them with problems in companies, lobbyists are in economic terms also the medium between the companies and the government. All the more so, since the representatives of state institutions are interested to hear what the consultant has to present on behalf of the interest group or client.

So, in an effort to implement a change, arrange some law or directive, the company will launch an advocacy campaign by hiring professional consultant or a lobbyist. The function of lobbyists in companies is arranged inside PR sector with a mission to create a link between the company and its environment. Creating and launching change is primary lobbyists task. There are different modalities for individuals in organisation to respond on changes in the environment. We're talking about anticipation of change, acting in accordance with the changes and studying them; and that the consultants are not ones who watch and wait, already activly participate in implementing the necessary changes.

Lobbyists usually act on the legislative and executive bodies, which is why lobbying can identify as one of the most important intermediaries between Parliament and influential public, and has a role in various aspects of public relations. Although in its essence and content, lobbying and public relations are similar, connected, and overlapped in many aspects, it is necessary to make difference between these two terms, and two different process. It is necessary to promote the interests of the company in both ways, through public relations and also with lobbying. 
In function of realization of the interests of the companies, lobbyists can implement appropriate campaign which represents a segment of the overall communications program. Using lobbying techniques, they implemented ideas through contemporary models of public relations. For example, lobbyists tend to activities related to the protection of the consumer and market put into acceptable legal frame, which means that their efforts affect on curbing corruption. (Krsmanović, 2013, p. 6)

In order to promote the interests of the company with appropriate business communication, lobbyists must to create contacts and disseminate information in different directions of the business environment. His role is to actualize connection with influential persons from world of politics, media, science, with competitors, and once again confirm the fact that a good consultant has to have a large number of skills in various fields. The main role of lobbyists in the company is to arrange negotiation, meetings, to find new contacts, collect new informations and present them in time, to be versed into the business trends, and finally to analyse the competition. In order to successfully promote the interests of the company, lobbyists use as essential tools negotiation and influencing. Main resource of exploitation are connections and contacts, integrity, trust and professionalism is his capital.

The mass media perform a key connection and the most important mediator in communication between Government and organizations (especially individuals), concerning that it is unrealistic to expect that the companies get all necessary information directly from the official institutions. In that kind of situation the consultant should be also an expert in public relations in order to present information properly through mass media and thus gained confidence in the course of realization of their activities. He should know to recognize the right moment when some information may be used in the right way for accomplishing activities.

Socially responsible companies are in continuous contact with the representatives of authorities, informing them about their business, trends and future plans. The state and its institutions are constantly working on improving the laws, and also upgrading organization of the business environment. This only confirms misleading that the benefit of lobbying could have only certain companies, actually It's the opposite. With lobbying the state gets the opportunity to realize their own interests and aims of crucial importance for the whole society.

Aware of the fact that lobbying is mutual exchange of information with influential subjects from the environment, whose decisions may significantly to affect on the future course of their business, managers in great companies are forced to work on the harmonization of the flow of information. It's quite expected that for the lobbying, large companies spend substantial amounts of money. To small and medium-sized companies in these processes should help from the state.

\section{Conclusion}

Success in business, company can achieve insofar as establish an adequate business communication with the environment. To be successful in communication with business partners, improve communication with main stakeholders in the state and society is significant request for each company. Good and successful communication can increase profits, so poor communication can reduce the same.

Should not forget that it all starts with fulfilling the needs and requests of the target market. Actually everything starts with the process of communication. To achieve successful results during its transformation enterprise can only come insofar as their 
orientation is based on improving the various elements. This orientation of the company may refer to: products, technology, production processes, customers, competition, market, etc. Following the innovation and technological progress, at the global market will survive enterprises that are able to adapt to the rules of the game imposed by new business trends. Economic sustainability, making compromise, the introduction the latest equipment and management systems and understanding political situation in the country becomes crucial matter. The state regulations and political environment can affect on business development, functioning of the economy and, above all, the survival of the company. Many enterprises, especially small and medium, as bearers of economic development of the national economy can not survive in the market in terms of globalization without state support. Reason for that is fact they are first to suffer when comes to public decisions, because they do not have sufficient resources to ensure a presence at meetings where comes to decisions relevant to their business.

Directed towards professional promotion, advancement or protection of particular interest of companies, lobbying as an activity undertaken with goal in order to influence the work of the legislature or the executive authorities. Lobbying provide easier way to articulate the interests and forward to public officials in order to attract their attention and eventually gain their support. It is an economic instrument whereby the economic subjects actively involved in the decision-making process. The lobbyists use as essential tools in order to promote the interests of the company is negotiation, main resource of exploitation are connections and contacts, his capital are integrity, trust and professionalism. Today we have more and more lobbyists, which use ability to influence together with the public relations techniques.

Improved communication techniques can lead to positive response of the investors, the overall economic competitiveness and transparency of public institutions. Expected aims of promoting interests of the company are classified into two groups: those that the company is trying to achieve by preventing the adoption of specific decisions; which will be realized if substantially change the given decision; goals which will be achieved if the implementation of specific decisions postpone for an indefinite period or those that can be achieved by creating problem with political background influencing in discussion about the issue that is important for a given company.

\section{References}

Blek, S., (2009), Odnosi sa javnošcu, CLIO, Beograd,

Bouwen, P., (2002), Corporate lobbying in the eu: The logic of access, Journal of European Public Policy,

Cornelissen, J., (2004), Corporate Communcations - Thory and Practice, Sage Publications

Clamen, M., (2004), Lobiranje, Clio, Beograd

Dolphin, R.R. (2000), Th Fundamentals of Corporate Communication, ButterworthHeinemann

Dobrijević, G., (2015), Poslovno komuniciranje i pregovaranje, Univerzitet Singidunum, Beograd

Djordjević, M., (2011), Korporativne komunikacije i upravljanje odnosima sa stejkholderima, Marketing

Djordejvić, B., (2014), Modeli vladanja tržištem, Sven, Niš, 
Heath R., i W. Timothy, Coombs Today's Public Relations - An Introduction, 2008.

Hamel, G. and B. Breen, (2007), The Future of Management, Harvard Busines School Press, Boston

Krsmanović, D., (2013), Vodič kroz lobiranje, Konrad Adenauer ZKonrad Adenauer Stiftung, Beograd,

Kašćelan, B. i D. Krsmanović, (2012), Političko i ekonomsko lobiranje, Zavod za udžbenike, Beograd

Klepić, Z. i M. Buble, (2007), Medadžment malih preduzeća osnove preduzetništva, Sveučilište, Mostar,

Langford-Wood, N., Salter, B., (2002), Critical Corporate Communications, John Wiley \& Sons

Miletić, S., (2010), Istraživanje tržišta, Ekonomski fakultet, Kosovska Mitrovica

Spahić, B., (2006), Lobiranje kao sastavni dio poslovnog komuniciranja u EU, Sarajevo

Trbović, A, (2014), Konkurentnost malih i srednjih preduzeća, FEFA, Beograd

Ćirković, D., (2013), Državna pomoć u funkciji razvoja konkurentnosti, FEFA, Beograd

http://www.poslovnaznanja.com/objavljeni-autorski-tekstovi/e-magazin/

http//www. rs.wikipedia.org/wiki/Lobiranje

http//www.gendar.rs/Poslovno-komuniciranje.aspx

www.co.rs/ODNOSI SA JAVNOSCU/OdnosiSaJavnoscu-.html 